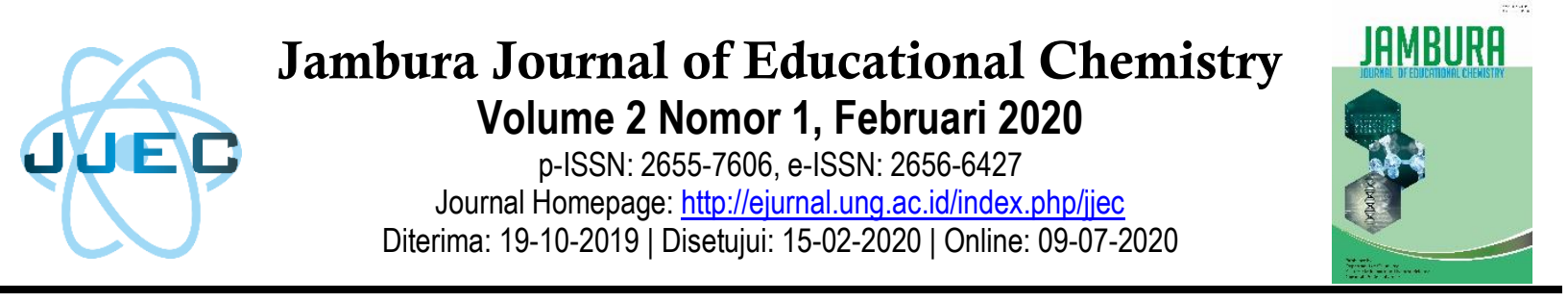

\title{
Penerapan Model Quantum Learning Sebagai Upaya Menurunkan Kejenuhan Belajar Siswa Dalam Mempelajari Kimia
}

\author{
Lilis Lisnawati ${ }^{1}$, Siti Suryaningsih², Buchori Muslim³ \\ 1,2,3Program Studi Pendidikan Kimia, Fakultas Ilmu Tarbiyah dan Keguruan, Universitas \\ Islam Negeri Syarif Hidayatullah Jakarta, Jl. Ir. H. Juanda No. 95, Ciputat 15412, Indonesia \\ Email: 1 lilisnawati580@gmail.com
}

\begin{abstract}
Abstrak
Siswa pada umumnya mengalami kejenuhan pada pembelajaran kimia. Penelitian ini bertujuan untuk mengetahui penerapan model quantum learning sebagai upaya menurunkan kejenuhan belajar siswa dalam mempelajari kimia. Penelitian ini adalah kuantitatif dengan jenis penelitian quasi eksperiment menggunakan desain matching pretest-posttest control group design. Populasi dalam penelitian ini adalah seluruh siswa di salah satu Sekolah Menengah Atas Swasta. Sampel penelitian menggunakan teknik purposive sampling. Pengumpulan data mempergunakan teknik non tes, instrumen berupa kuesioner kejenuhan belajar. Teknik analisis data menggunakan SPSS versi 20. Hasil uji hipotesis menggunakan uji Mann-Whitney dari data N-gain yaitu sig.(2-tailed) = 0,093 / 2 $=0.0465<0,05$ atau $\mathrm{H}_{0}$ ditolak. Hal tersebut menunjukkan bahwa penerapan model quantum learning berperan sebagai upaya menurunkan kejenuhan belajar siswa dalam mempelajari kimia. Hasil penelitian ini dapat dijadikan sebagai rekomendasi bagi para guru untuk diterapkan dalam kegiatan pembelajaran kimia di sekolah yang dapat menurunkan kejenuhan belajar siswa dalam mata pelajaran kimia.
\end{abstract}

Kata Kunci: Kejenuhan Belajar, Quantum Learning, Siswa

\section{PENDAHULUAN}

Proses pembelajaran kimia di sekolah selama ini terlihat kurang menarik, membuat peserta didik kurang memiliki minat merasa penat dan pada pelajaran kimia, hal ini menjadikan suasana kelas condong pasif, dan tidak banyak peserta didik yang berani bertanya kepada pendidik, dengan sebab pelajaran yang diajarkan belum bisa dimengerti, bahkan setelah dijelaskan kembali masih ada yang cukup sulit untuk memahami pelajaran yang diberikan. Jiwa mereka tertekan karena seakan-akan dipaksa untuk belajar, kondisi seperti itu membuat mereka gusar, kebosanan, masa bodoh, sehingga motivasi, perhatian, minat, siswa dalam studi kimia rendah. Hal ini memiliki dampak terhadap ketidakberhasilnya tujuan pembelajaran kimia yang akan dicapai (Sunyono et al., 2009).

Ketika siswa tidak dapat mengatasi keadaan di bawah stres dan tekanan untuk waktu yang lama, mereka mengalami gejala-gejala kelelahan yang berasal dari sekolah. Kelelahan tersebut menyebabkan hal yang serius seperti depresi, absensi sekolah, kehilangan motivasi, putus sekolah, dan bunuh diri, menunjukkan gejala dalam tiga dimensi: fisik, afektif, dan kognitif (Aypay, 2017). Kejenuhan sekolah merupakan kelelahan karena mempelajari tuntutan, sikap sinis terhadap sekolah, dan perasaan tidak mampu sebagai siswa. Tuntutan studi mungkin menyebabkan perasaan kelelahan, tuntutan studi 
merupakan faktor penentu kejenuhan sekolah. Misalnya, stres belajar dapat diartikan sebagai permintaan dirasakan oleh siswa bahwa mereka menyesuaikan diri dengan sekolah. Kejenuhan di sekolah juga telah dikaitkan dengan kebosanan (Aro \& Katja, 2014).

Salah satu tugas yang harus dilaksanakan oleh guru di sekolah ialah memberikan pelayanan kepada para siswa agar mereka menjadi siswa atau anak didik yang selaras dengan tujuan pembelajaran. Guru merupakan faktor utama yang bertugas sebagi pendidik di dalam keseluruhan mekanisme pendidikan. Guru wajib bertanggung jawab atas hasil kegiatan belajar mengajar melalui interaksi belajar-mengajar dan juga harus menguasai prinsip-prinsip belajar di samping menguasai materi yang akan diajarkan, karena guru merupakan faktor yang mempengaruhi berhasil tidaknya proses belajar. Dengan kata lain: Guru wajib bisa menciptakan suasana belajar yang sangat baik (Hamalik, 2010). Menurut Zeybek (2017) untuk menyesuaikan diri dengan ini, orang harus meningkatkan keterampilan dan kemampuan mereka secara efektif; karenanya, berbagai metode dan teknik telah dikembangkan dalam pendidikan. Salah satunya adalah model Quantum Learning yang menjadi meluas. Sujatmika et al., (2018) masih ada masalah yang menjadi kendala dalam pendidikan seperti rendahnya kualitas pembelajaran di sekolah. Pendidik, dalam hal ini, guru atau dosen harus menggunakan metode atau model pembelajaran yang sesuai dengan kebutuhan.

Menurut Ramlan (2017) metode quantum learning merupakan salah satu inovasi dalam dunia pendidikan, Bobby De Porter merupakan pengembang metode ini dengan beranggapan bahwa metode ini cocok dengan cara belajar manusia dan sistem kerja otak manusia pada umumnya. Pada penelitian ini peneliti akan meneliti tentang "Penerapan Model Quantum Learning Sebagai Upaya Menurunkan Kejenuhan Belajar Siswa Dalam Mempelajari Kimia" Peneliti menganggap penelitian ini penting karena model Quantum Learning adalah salah satu model pembelajaran yang dapat mengaktifkan siswa, menyenangkan, dan memacu siswa untuk menggunakan semua potensi yang dimiliki. Selain itu model pembelajaran quantum juga meninjau gaya belajar visual, auditorial, dan kinestetik. Hal ini diharapkan dapat membuat siswa merasa nyaman dengan pembelajaran kimia sehingga dapat menurunkan kejenuhan siswa dalam pelajaran kimia.

Perlu diciptakannya sistem lingkungan (kondisi) belajar yang lebih kondusif dalam usaha pencapaian tujuan belajar yang akan berkaitan dengan mengajar. Mengajar diartikan dengan usaha menciptakan sistem lingkungan yang baik yang menunjang terjadinya proses belajar. Sistem lingkungan belajar ini terdiri atau dipengaruhi oleh berbagai komponen yang masing-masing akan saling memengaruhi. Komponen-komponen itu seperti seperti apa pembelajaran yang ingin dicapai, hal-hal apa yang akan diajarkan, pendidik dan peserta didik yang melaksanakan peran serta dalam hubungan sosial tertentu, model kegiatan yang dilaksanakan, serta sarana prasarana yang tersedia. Setiap peristiwa belajar memiliki profil yang unik dan kompleks, karena antara komponenkomponen sistem lingkungan ini saling memengaruhi secara bervariasi. setiap profil sistem lingkungan belajar, untuk tujuan belajar yang berbeda.

Dengan bahasa lain, harus diciptakan sistem lingkungan belajar sedemikian rupa untuk mencapai tujuan belajar yang diharapkan. Tujuan belajar pengembangan gerak memerlukan penciptaan sistem lingkungan yang berbeda dengan sistem yang dibutuhkan dari tujuan belajar pengembangan nilai afeksi, dan begitu seterusnya. Jika dilihat, tujuan-tujuan belajar sangat bervariasi dan banyak. Misalnya tujuan belajar yang dicapai dengan instructional effects (tindakan instruksional) biasanya digunakan dengan tujuan belajar yang eksplisit, biasanya menggunakan bentuk pengetahuan dan keterampilan. Menghidupi (to live in) suatu sistem lingkungan belajar tertentu seperti contohnya, kemampuan berpikir kritis dan demokratis, kreatif, sikap terbuka, dan menerima pendapat orang lain, semuanya itu termasuk dalam nurturant effects. Nurturant effect ini bertujuan lebih kepada hasil sampingan. Jadi pendidik harus sudah menetapkan 
strategi dan rencana dalam belajar-mengajar agar mencapai instructional effects, atau kedua-duanya (Sardiman, 2014).

Quantum Learning berawal dari usaha Dr.Georgi Lozanov, seorang pengajar berkebangsaan Bulgaria yang membuat penelitian dengan hal yang disebutnya sebagai "suggestology" ataut "suggestopedia". Prinsipnya adalah bahwa sugesti dapat dan pasti memengaruhi hasil situasi belajar, dan setiap perincian apapun memberikan sugesti positif ataupun negatif. Sebagian teknik yang digunakannya untuk memberikan sugesti positif ialah memberi tempat duduk yang nyaman, menyetel musik di dalam kelas, meningkatkan keikutsertaan murid, memakai poster-poster untuk menciptakan kesan yang hebat sembari memberikan informasi, dan menyediakan guru-guru yang professional dalam seni sugestif (DePorter \& Mike, 2007). Quantum Learning adalah kombinasi dari banyak interaksi yang ada selama pembelajaran. Model ini dapat diterapkan oleh topik yang menarik saat ini, kontekstual, berulang-ulang, dan memberikan kesempatan kepada siswa untuk menunjukkan kemampuan mereka. Dasar dari model quantum learning yang tersisa teori otak, teori otak kanan, tritunggal, visual, auditorial, kinestetik, permainan, simbol, holistik, dan teori experiential learning. Kreativitas memainkan peran penting untuk menjadi sukses di dunia kerja (Sujatmika et al., 2018).

Sejarah di bidang pendidikan juga, seperti pembacaan konsep dan pendekatan. Aspek teoritis Quantum Learning ditujukan untuk memberikan pembelajaran yang lebih cepat dan menyenangkan dengan menghabiskan siswa sedikit energi. Dipercepat dengan teknik belajar dan NLP (Neurolinguistic Programming), berbasis otak belajar, gaya belajar, pendekatan kecerdasan ganda, teori otak tiga, holistik (menyeluruh) pendekatan kontemporer untuk prinsip-prinsip seperti pendidikan. Informasi yang masuk pada quantum learning melalui jaringan saraf di otak untuk mendefinisikan bentuk kombinasi struktur untuk lingkungan pembelajaran berbasis otak yang menekankan pendekatan belajar (Güler \& Yazici, 2018).
Quantum Learning merupakan model yang didasarkan pada tahun 1980-an ketika perkembangan ilmiah yang diperoleh dengan percepatan. Dasar model ini bergantung pada teknik pembelajaran dipercepat disampaikan oleh Dr. Georgi Lazanov, dan penggunaan teknik pembelajaran dengan strategi kompatibel dengan otak. Bahkan didasarkan pada pendekatan menggunakan perbedaan fungsi otak sebagai dua orang pemain dan teori otak threesome, dan itu termasuk prinsip-prinsip teori multiple intelligence melihat dari perspektif manusia. Didukung dengan pendekatan yang memberikan pelajaran kepada peserta didik baik perkembangan fisik dan mental di pendidikan sebagai holistic.

Quantum Learning didasarkan pada lima prinsip utama (1) Bahasa tubuh, perencanaan catatan kuliah, lingkungan kelas, dan lainnya semua ada di lingkungan belajar. lingkungan belajar yang tepat meliputi cahaya yang cukup, tanaman, warna, musik dan alat peraga. (2) Semuanya dilakukan sesuai dengan tujuannya. Ini terjadi bila pelajaran diperkirakan dengan cara hati-hati seperti halnya orkestra. (3) Otak dapat lebih berhasil jika dirangsang oleh stimulan yang rumit. Jika ide-ide baru yang terkait dengan halhal yang diperoleh tanpa belajar, belajar mungkin lebih efektif. (4) Belajar meliputi risiko. Tetapi jika lingkungan belajar diatur nikmat, belajar mungkin lebih mudah. Jika pelajar mengikuti langkah ini, ia menganggap aman dan mungkin bisa berhasil. (5) Jika ada sesuatu yang patut dipelajari itu juga patut dirayakan, karena, umpan balik membuat positif hubungan emosional dengan belajar.

Para siswa mengambil peran aktif dalam quantum learning. Membaca cepat efektif dalam memungkinkan siswa untuk mendapatkan informasi dalam waktu singkat. Otak berfokus pada topik yang lebih baik di bacaan. Membaca mempengaruhi mempertimbangkan kecepatan juga. Membaca cepat adalah suatu teknik yang dapat sering digunakan dalam ujian, pekerjaan rumah dan pemindaian sumber daya oleh siswa (Acat, 2014).

Quantum learning terdiri dari enam tahap terikat untuk saling melengkapi dan saling korelatif. Tahap ini terdiri dari tumbuhkan, alami, 
namai, demonstrasi, ulangi dan rayakan. (1) Tumbuhkan: Ini adalah tahap penting dari keterampilan belajar mandiri, fenomena kebutuhan siswa dalam pembelajarantharus diperoleh. Ini ditujukan agar para siswa mengambil alih situasi dengan menghadirkan solusi mereka sendiri untuk masalah yang mereka hadapi (Acat, 2014). (2) Alami: Pengalaman atau kegiatan memperkenalkan disebutkan untuk memungkinkan mereka untuk menemukan hubungan yang memeriksa pengetahuan mereka sebelumnya tentang subjek dan untuk menciptakan kebutuhan pengetahuan yang menyediakan makna dan minat pada konten pembelajaran. Pada tahap mengalami, mnemotechnik (memori mengembangkan teknik dengan manfaat dari latihan dengan tim dan kelompok kegiatan dan asosiasi). (3) Namai: Membahas relevansi siswa dengan kehidupan setelah menyediakan relevansi dengan topik pada tahap namai. Quantum mencatat, teknik memori, grafis, poster dan strategi penelitian kuantum dapat digunakan pada tahap ini (Acat, 2014). (4) Demonstrasi: Memberikan para siswa dengan kesempatan untuk mereka beradaptasi dari topik terkait belajar untuk situasi lain. Memberi mereka kegiatan tambahan di mana mereka dapat menerapkan hal yang mereka pelajari dengan memberi mereka kepercayaan diri dengan membuat mereka melihat apa yang mereka ketahui. (5) Ulangi: Ini adalah tahap di mana pengetahuan dan keterampilan yang diperoleh dipaku di otak. Mengulangi memastikan kekuatan keberanian untuk memperkuat dan konten untuk mengambil tempat dalam pikiran (Acat, 2014). (6) Rayakan: Menurut Acat (2014) merayakan keberhasilan siswa pada tahap ini akan memberikan hubungan dekat untuk menghormati usaha, belajar dengan penuh perhatian dan merasa sukses. Berbagai kegiatan dapat digunakan pada tahap perayaan. Pemberian kontes yang baik, menghibur dan membuat mereka menikmati untuk memperoleh pengetahuan baru pada akhir pelajaran dapat diterapkan.

Istilah "kejenuhan" digunakan untuk menggambarkan sindrom kelelahan. Kejenuhan adalah sindrom kelelahan emosional dan sinisme yang sering menimpa diri seseorang. Sebuah aspek kunci dari sindrom kejenuhan adalah meningkatnya perasaan kelelahan emosional. Aspek lain adalah pengembangan negatif, sikap sinis dan perasaan tentang seseorang (Yavuz \& Dogan, 2014). Kelelahan mengacu pada perasaan yang berlebihan dan habis sumber daya seseorang emosional dan fisik (Maslach \& Leiter, 2007). Selain itu arti kejenuhan adalah penuh atau padat sehingga tidak dapat lagi menampung apapun. Di samping itu, jenuh juga dapat berarti jemu atau bosan. Dalam belajar, selain siswa sering mengalami kelupaan, ia juga terkadang mengalami peristiwa-peristiwa negatif lainnya yang disebut kejenuhan belajar yang dalam bahasa psikologi biasa disebut learning plateau atau plateau (baca: pletou). Kejenuhan ini jika dialami seorang murid yang sedang dalam proses belajar (kejenuhan belajar) dapat menjadikan murid tersebut merasa telah menyia-nyiakan usahanya (Syah, 2013).

Beberapa studi tentang kejenuhan sekolah telah menyelidiki faktor- faktor yang mungkin memiliki efek yang dapat menjelaskan dampaknya. Kejenuhan sekolah telah dikaitkan dengan kondisi negative, termasuk fungsi fisiologis. Kejenuhan sekolah telah ditemukan di sekolah menengah, Sekolah Menengah Atas (SMA), Sarjana, dan mahasiswa pascasarjana (Seibert et al., 2016). Seorang murid yang mengalami kejenuhan belajar merasa seakan-akan pengetahuan dan kebisaan yang didapatnya dari belajar tidak memiliki kemajuan. Tidak adanya kemajuan hasil bełajar ini biasanya tidak berlangsung selamanya, tetapi dalam rentang waktu tertentu saja, misalnya beberapa hari. Tetapi, banyak juga murid yang mengalami rentang waktu yang membawa kejenuhan itu berkali-kali dalam satu periode belajar tertentu. Seorang Murid yang sedang dalam keadaan jenuh, sistem otaknya tidak bisa bekerja seperti yang diharapkan dalam memproses materi-materi atau pengalaman baru, sehingga kemajuan belajar seolah-olah hanya "jalan di tempat". Jika perkembangan belajar yang jalan di tempat ini kita gambarkan dalam bentuk kurva, yang akan tampak adalah garis mendatar yang biasa disebut plateau (Syah, 2013). 
Berdasarkan permasalahan di atas, penelitian ini dilakukan untuk mengetahui penerapan model quantum learning sebagai upaya menurunkan kejenuhan belajar siswa dalam mempelajari kimia.

\section{METODE PENELITIAN Jenis penelitian}

Penelitian ini menggunakan pendekatan kuantitatif. Jenis penelitian quasi eksperiment menggunakan desain matching pretest-posttest control group design.

\section{Waktu dan Tempat Penelitian}

Penelitian ini dilaksanakan di salah satu Sekolah Menengah Atas Swasta (SMA S) Bojongsari, Depok. Penelitian dilaksanakan pada semester genap Tahun Pelajaran 2018/2019 dari tanggal 9-11 April 2019.

\section{Target/ Subjek Penelitian}

Populasi dalam penelitian ini adalah seluruh siswa disalah satu Sekolah Menengah Atas Swasta Kota Depok. Pengambilan sampel menggunakan teknik purposive sampling. Sampel penelitian ini adalah siswa kelas X IPA 1 dan X IPA 2.

\section{Data, Instrumen, dan Teknik Pengumpulan Data}

Instrumennya mengadaptasi dari instrumen kejenuhan belajar milik Mubiar Agustin sebanyak 40 item pernyataan. Pengumpulan data mempergunakan teknik non tes, instrumen berupa kuesioner kejenuhan belajar.

\section{Teknik analisis data}

Teknik analisis data menggunakan SPSS versi 20.

\section{HASIL DAN PEMBAHASAN}

Data hasil penelitian diperoleh dari angket kejenuhan belajar siswa. Angket awal diberikan sebelum pembelajaran materi tata nama senyawa kimia sederhana dan angket akhir diberikan setelah pembelajaran materi tata nama senyawa kimia sederhana. Berikut ini hasil penelitian yang diperoleh dari kelas eksperimen dan kontrol. Berdasarkan skor pretest dan posttest kejenuhan belajar siswa, data tersebut terlihat penurunan dari pretest ke posttest. Perbandingan nilai rata-rata pretest dan posttest kejenuhan belajar siswa disajikan pada Gambar 1 berikut.

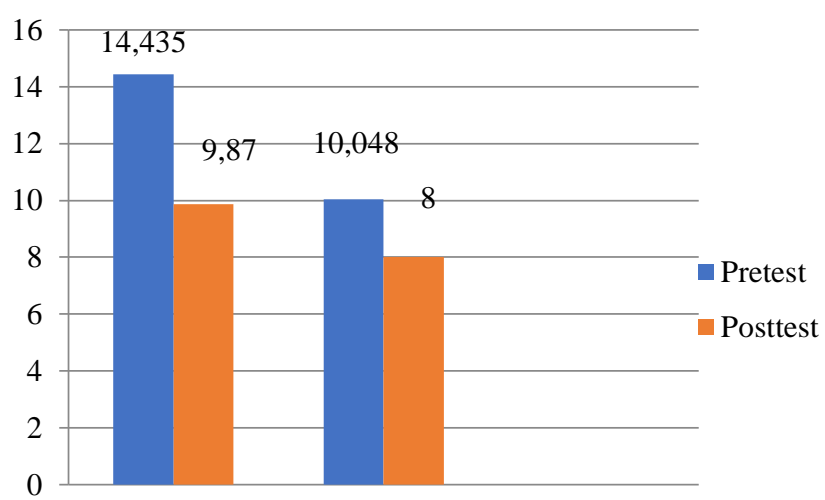

Kelas Eksperimen Kelas Kontrol

Gambar 1. Nilai Rata-rata Pretest dan Posttest Kejenuhan Belajar Siswa

Berdasarkan Gambar 1. bahwa siswa pada kelas eksperimen dan kontrol memiliki tingkat kejenuhan yang berbeda. Hal ini terlihat rata-rata skor pretest kelas eksperimen sebesar 14.435 dan kelas kontrol sebesar 10.048. Setelah penerapan model quantum learning dalam pembelajaran kimia rata-rata skor posttest kelas eksperimen sebesar 9.870 dan kelas kontrol sebesar 8 . Hal ini dapat menunjukkan bahwa penerapan model quantum learning berperan sebagai upaya menurunkan kejenuhan belajar siswa dalam mempelajari kimia.

Berdasarkan skor pretest dan posttest kejenuhan belajar siswa didapatkan skor $\mathrm{N}$-gain. Skor tersebut mengindikasikan adanya penurunan kejenuhan. Rata-rata N-gain kejenuhan belajar siswa disajikan pada Gambar 2. berikut.

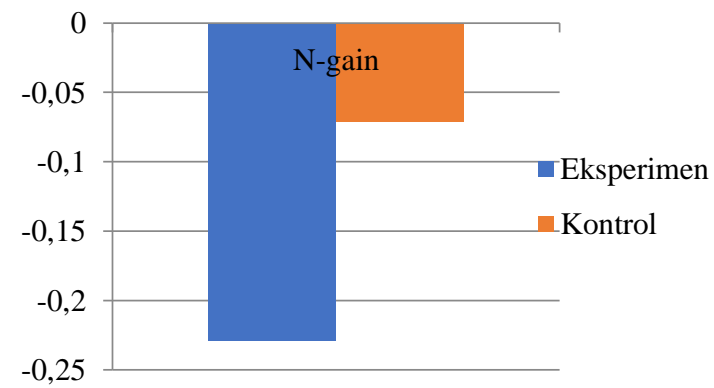

Gambar 2. Rata-rata N-gain Kejenuhan Belajar Siswa 
Berdasarkan Gambar 2 bahwa Skor N-gain kejenuhan siswa bernilai negatif karena pada analisis kejenuhan terjadi penurunan kejenuhan belajar setelah diberikan perlakuan model quantum learning dan model direct instruction. Skor N-gain kelas eksperimen lebih banyak mengalami penurunan dibandingan kelas kontrol. Rata-rata skor N-gain mengindikasikan bahwa model quantum learning memiliki peranan yang lebih baik terhadap penurunan kejenuhan belajar siswa dibandingkan dengan model direct instrcuction.

Uji statistik yang digunakan untuk mengetahui kedua kelas memiliki kejenuhan awal yang sama atau tidak adalah uji perbedaan rerata. Oleh sebab itu, sebelum dilakukan uji perbedaan rerata, data skor pretest dan posttest di uji normalitas dan homogenitas. Berdasarkan hasil uji normalitas disajikan pada Tabel 1. berikut.

Tabel 1. Hasil Uji Normalitas

\begin{tabular}{|c|c|c|c|}
\hline \multicolumn{2}{|c|}{ Data } & Sig & Kesimpulan \\
\hline Pretest & $\begin{array}{c}\text { Kelas } \\
\text { Eksperimen }\end{array}$ & 0.059 & $\begin{array}{c}\text { Berdistribusi } \\
\text { normal }\end{array}$ \\
\hline \multirow{3}{*}{ Posttest } & $\begin{array}{c}\text { Kelas } \\
\text { Kontrol }\end{array}$ & 0.371 & $\begin{array}{l}\text { Berdistribusi } \\
\text { normal }\end{array}$ \\
\hline & $\begin{array}{c}\text { Kelas } \\
\text { Eksperimen }\end{array}$ & 0.990 & $\begin{array}{c}\text { Berdistribusi } \\
\text { normal }\end{array}$ \\
\hline & $\begin{array}{l}\text { Kelas } \\
\text { Kontrol }\end{array}$ & 0.059 & $\begin{array}{c}\text { Berdistribusi } \\
\text { normal }\end{array}$ \\
\hline
\end{tabular}

Berdasarkan Tabel 1. hasil uji normalitas untuk data pretest kelas eksperimen dan kelas kontrol berdistribusi normal begitupun posttest keduanya berdistribusi normal. Hal ini menunjukkan bahwa data pretest dan posttest kelas eksperimen dan kontrol berdistribusi normal. Selanjutnya, data tersebut diuji homogenitas pada kelas eksperimen dan kontrol. Berdasarkan hasil uji homogenitas disajikan pada Tabel 2. berikut.

Tabel 2. Hasil Uji Homogenitas

\begin{tabular}{cccc}
\hline \multicolumn{2}{c}{ Data } & Sig & Kesimpulan \\
\hline \multirow{2}{*}{ Pretest } & Kelas & & \\
& Eksperimen & 0.592 & Homogen \\
& Kelas & & \\
& Kontrol & & \\
Posttest & Kelas & & \\
& Eksperimen & 0.190 & Homogen \\
& Kelas & & \\
\hline
\end{tabular}

Berdasarkan Tabel 2, hasil uji homogenitas untuk data pretest kelas eksperimen dan kontrol homogen begitupun posttest keduanya homogen. Hal ini menunjukkan bahwa pretest dan posttest kelas eksperimen dan kontrol homogen.

Berdasarkan uji normalitas dan homogenitas skor pretest kejenuhan belajar siswa dapat disimpulkan bahwa data pretest berdistribusi normal dan homogen. Oleh sebab itu, untuk menguji perbedaan rerata dilakukan uji parametrik Independent Sampel T Test. Kemudian di uji normalitas dan homogenitas pada skor $\mathrm{N}$-gain. Berikut hasil uji independent sample t test pretest kelas eksperimen dan kontrol serta uji normalitas ngain kejenuhan belajar kelas eksperimen dan kelas kontrol disajikan pada Tabel 3. berikut.

Tabel 3. Uji Independent Sample T Test Pretest Kelas Eksperimen dan Kontrol serta Uji Normalitas N-gain Kejenuhan Belajar Kelas Eksperimen dan Kelas Kontrol

\begin{tabular}{|c|c|c|c|}
\hline \multicolumn{2}{|c|}{ Data } & Sig & Kesimpulan \\
\hline $\begin{array}{c}\mathrm{Uji} \\
\text { Independent } \\
\text { Sample T }\end{array}$ & $\begin{array}{c}\text { Kelas } \\
\text { Eksperimen } \\
\text { Kelas }\end{array}$ & $\begin{array}{l}\text { Sig. } \\
(2- \\
\text { tailed) }\end{array}$ & $\mathrm{H}_{0}$ ditolak \\
\hline Test Pretest & Kontrol & 0.005 & \\
\hline Uji & $\begin{array}{c}\text { Kelas } \\
\text { Eksperimen }\end{array}$ & 0.000 & $\begin{array}{l}\text { Berdistribusi } \\
\text { tidak normal }\end{array}$ \\
\hline $\begin{array}{l}\text { Normalitas } \\
\text { N-gain }\end{array}$ & $\begin{array}{l}\text { Kelas } \\
\text { Kontrol }\end{array}$ & 0.845 & $\begin{array}{c}\text { Berdistribusi } \\
\text { normal }\end{array}$ \\
\hline
\end{tabular}

Berdasarkan Tabel 3, pada pretest kelas eksperimen dan kontrol diperoleh nilai sig.(2-tailed) $=0,005 / 2=0.0025<0,05$ sehingga $\mathrm{H}_{0}$ ditolak. Hal ini menunjukkan bahwa terdapat perbedaan yang signifikan antara pretest kejenuhan belajar siswa kelas eksperimen dan kelas kontrol. Pada uji normalitas $\mathrm{N}$-gain kelas eksperimen berdistribusi tidak normal dan $\mathrm{N}$-gain kelas kontrol berdistribusi normal.

Selanjutnya, data tersebut diuji homogenitas pada skor N-gain. Pengujian penurunan kejenuhan belajar siswa pada data Ngain dilakukan uji nonparametrik Mann-Whittney karena data $\mathrm{N}$-gain kelas eksperimen tidak berdistribusi normal dan data N-gain kelas eksperimen dan kontrol tidak homogen. Berikut hasil uji homogenitas $\mathrm{N}$-gain kejenuhan belajar 
kelas eksperimen dan kelas kontrol serta hasil uji hipotesis $\mathrm{N}$-gain disajikan pada Tabel 4. berikut.

Tabel 4. Uji Homogenitas N-gain Kejenuhan Belajar Kelas Eksperimen dan Kelas Kontrol serta Hasil Uji Hipotesis N-gain

\begin{tabular}{|c|c|c|c|}
\hline \multicolumn{2}{|c|}{ Data } & Sig & Kesimpulan \\
\hline $\begin{array}{c}\text { Uji } \\
\text { Homogenitas } \\
\text { N-gain }\end{array}$ & $\begin{array}{c}\text { Kelas } \\
\text { Eksperimen } \\
\text { Kelas } \\
\text { Kontrol }\end{array}$ & 0.043 & $\begin{array}{c}\text { Tidak } \\
\text { homogen }\end{array}$ \\
\hline $\begin{array}{l}\text { Uji Hipotesis } \\
\text { N-gain }\end{array}$ & $\begin{array}{c}\text { Kelas } \\
\text { Eksperimen } \\
\text { Kelas } \\
\text { Kontrol }\end{array}$ & $\begin{array}{c}\text { Sig. } \\
(\mathbf{2 -} \\
\text { tailed) } \\
0.093\end{array}$ & $\mathrm{H}_{0}$ ditolak \\
\hline
\end{tabular}

Berdasarkan Tabel 4, pada N-gain kelas eksperimen dan kontrol diperoleh 0.043 di mana kurang dari 0.05 . Hal ini menunjukkan bahwa $\mathrm{N}$ gain kelas eksperimen dan kontrol tidak homogen. Uji Hipotesis $\mathrm{N}$-gain dapat dilihat bahwa diperoleh sig.(2-tailed) $=0,093 / 2=0.0465<0,05$ maka $\mathrm{H}_{0}$ ditolak. Dengan demikian penerapan model quantum learning berperan sebagai upaya menurunkan kejenuhan belajar siswa dalam mempelajari kimia.

Pemberian kuesioner bertujuan untuk mengetahui perbedaan kejenuhan belajar siswa yang diajarkan dengan model quantum learning dengan model direct instruction diberikan sebelum dan sesudah pembelajaran. Data diperoleh dari pretest dan posttest kelas eksperimen dan kontrol yang kemudian diperoleh N-gain. Pada kelas eksperimen, dari 23 siswa terdapat nilai rata-rata pretest sebesar 14,435, posttest sebesar 9,870, dan diperoleh rata-rata $\mathrm{N}$-gain sebesar -0.229 menunjukkan bahwa siswa pada kelas eksperimen mengalami penurunan kejenuhan belajar. Pada kelas kontrol, dari 21 siswa terdapat nilai rata-rata pretest sebesar 10,048, posttest sebesar 8, dan diperoleh rata-rata $\mathrm{N}$-gain sebesar $-0,0713$ yang menunjukkan bahwa siswa kelas kontrol juga mengalami penurunan kejenuhan belajar. Dengan demikian kelas eksperimen dan kontrol mengalami penurunan kejenuhan belajar namun penurunan yang lebih besar terjadi pada kelas eksperimen. Penurunan kejenuhan belajar siswa lebih besar di kelas eksperimen dikarenakan model quantum learning adalah model pembelajaran yang nyaman dan menyenangkan sehingga dapat menurunkan kejenuhan yang lebih baik daripada model direct instruction). Siswa keadaan nyaman dengan dirinya lebih berpeluang memiliki coping strategi dalam mengatasi kejenuhan belajar (Suwidagdho, 2016). Setiap pembelajaran yang menyenangkan tidak membuat siswa jenuh mengikuti pelajaran (Rahayu et al., 2016).

Data pretest kelas eksperimen dan kontrol berdistribusi normal dan homogen. Maka dari itu diuji hipotesis dengan menggunakan uji Independent Samples Test untuk melihat perbedaan antara pretest kelas eksperimen dengan pretest kelas kontrol. Data menunjukkan bahwa diperoleh nilai sig. (2-tailed) atau p-value $=0,005 / 2=0.0025$ $<0,05$ yang artinya terdapat perbedaan antara pretest eksperimen dengan pretest kontrol. Dengan demikian uji hipotesis yang digunakan adalah uji hipotesis N-gain kelas eksperimen dan kontrol.

Pada uji normalitas, data $\mathrm{N}$-gain pada kelas eksperimen tidak berdistribusi normal dan pada kelas kontrol berdistribusi normal. Pada uji homogenitas, data tersebut tidak homogen. Maka dari itu uji hipotesis yang dilakukan menggunakan uji nonparametrik dengan uji Mann-Whitney. Berdasarkan uji Mann-Whitney diperoleh nilai sig. $(2$-tailed $)=0,093 / 2=0.0465<0,05$ atau $\mathrm{Ho}$ ditolak. Hal ini menunjukkan quantum learning berperan sebagai upaya menurunkan kejenuhan belajar siswa dalam mempelajari kimia

Hasil penelitian ini bisa dijelaskan karena model quantum learning adalah model pembelajaran yang nyaman dan menyenangkan. Menurut Sujatmika, Hasanah \& Hakim (2018) melalui quantum learning, siswa akan menggunakan semua kemampuan mereka. Mereka tertarik untuk belajar dan menciptakan cara-cara mereka sendiri dalam menghafal konsep materi yang dipelajari. Dalam hal ini siswa menghafal tata nama senyawa kimia sesuai dengan kemampuan mereka.

Menurut Syah (2013) keletihan yang melanda siswa merupakan penyebab kejenuhan yang paling umum. Keletihan dapat menjadi penyebab munculnya perasaan bosan pada siswa yang bersangkutan. Penerapan Model quantum 
learning dalam pembelajaran kimia terdiri dari enam tahap, yaitu: Tumbuhkan. Pada tahap ini guru memberikan motivasi berupa video motivasi, siswa terlihat sangat fokus, tidak mudah menyerah dan merasa bersemangat untuk belajar. Berdasarkan data yang diperoleh menunjukkan adanya penurunan kejenuhan sebanyak $15 \%$ dari rata-rata pretest sebesar 52\% menjadi $37 \%$ setelah diberi perlakuan pada aspek kelelahan emosi dengan 14 item pernyataan. Pada aspek kehilangan motivasi data yang diperoleh menunjukkan adanya penurunan kejenuhan sebanyak $10 \%$ dari rata-rata pretest sebesar $20 \%$ menjadi $10 \%$ setelah diberi perlakuan pada aspek kehilangan motivasi dengan 10 item pernyataan. Relevan dengan penelitian Iwantara (2014) yang menyatakan bahwa media video youtube dapat memotivasi siswa untuk belajar dan memberikan pengalaman belajar pada siswa dengan menghadirkan sesuatu yang dapat dilihat dan didengar. Setelah itu guru membacakan tujuan pelajaran untuk mengetahui Apa Manfaat Bagiku (AMBAK), siswa terlihat untuk minat kembali dalam belajar sehingga dirinya tidak merasa gagal dalam belajar. Bila didorong dengan motivasi, belajar akan lebih mantap dan efektif, terutama motivasi dari dalam/dasar kebutuhan/kesadaran atau intrinsic motivation, lain halnya belajar dengan rasa takut atau dibarengi dengan rasa tertekan dan menderita. (Sardiman, 2014). Tahapan ini indikator kejenuhan kehilangan semangat belajar, mudah menyerah, kehilangan minat belajar pada aspek kehilangan motivasi serta indikator kejenuhan merasa gagal dalam belajar pada aspek kelelahan emosi dapat diatasi.

Alami. Selain guru memberikan pengalaman (memberikan materi) guru meminta siswa terlebih dahulu untuk membaca dan menulis apa yang ia ketahui tentang tata nama senyawa kimia yang bertujuan untuk meningkatkan hasrat alami otak untuk menjelajah. Pada tahap ini siswa terlihat berkonsentrasi dalam membaca. Setelah itu perwakilan siswa menjelaskan apa yang ia baca di depan kelas dengan mengingat dan membaca. Berdasarkan data yang diperoleh menunjukkan adanya penurunan kejenuhan sebanyak $10 \%$ dari rata-rata pretest sebesar 35\% menjadi $25 \%$ setelah diberi perlakuan pada aspek kelelahan kognitif dengan 11 item pernyataan. Membaca cepat, efektif dalam memungkinkan siswa untuk mendapatkan informasi dalam waktu singkat (Acat, 2014). Quantum learning dapat meningkatkan kemampuan membaca siswa (Martika \& Hermayawati, 2016). Indikator kejenuhan kesulitan berkonsentrasi dan mudah lupa dalam belajar pada aspek kejenuhan kelelahan kognitif dalam tahap ini dapat diatasi.

Namai. Pada tahap ini menamai unsur senyawa kimia sederhana. Pada tahap ini siswa sangat antusias saling bekerjasama untuk menamai unsur dengan benar, dengan berkonsentrasi menjawab pertanyaan dan mengingat kembali materi yang dipelajari. Berdasarkan data yang diperoleh menunjukkan adanya penurunan kejenuhan sebanyak $10 \%$ dari rata-rata pretest sebesar 35\% menjadi $25 \%$ setelah diberi perlakuan pada aspek kelelahan kognitif dengan 11 item pernyataan. Pada tahap ini indikator kejenuhan kesulitan berkonsentrasi dan mudah lupa dalam belajar, enggan membantu dalam kegiatan belajar, kehilangan gairah dan kekuatan untuk belajar pada aspek kejenuhan kelelahan kognitif dapat diatasi. Hal ini relevan dengan Sujatmika et al., (2018) memori yang baik memainkan peran dalam keberhasilan pembelajaran.

Demonstrasikan. Pada tahap ini perwakilan siswa maju ke depan untuk mendemonstrasikan senyawa dengan molymod. Siswa percaya diri maju ke depan untuk mendemonstrasikannya dan menunjukkan kemampuannya sehingga tidak mudah menyerah. Pada aspek kehilangan motivasi data yang diperoleh menunjukkan adanya penurunan kejenuhan sebanyak $10 \%$ dari rata-rata pretest sebesar $20 \%$ menjadi $10 \%$ setelah diberi perlakuan pada aspek kehilangan motivasi dengan 10 item pernyataan. Pada tahap ini indikator kejenuhan mudah menyerah pada aspek kehilangan motivasi dapat diatasi. Belajar pada hakikatnya menyangkut potensi manusiawi dan kelakuannya (Sardiman, 2014).

Ulangi. Pada tahap ini siswa menyimpulkan pelajaran yang telah dipelajari dengan mengulangi sehingga tidak mudah lupa. 
Berdasarkan data yang diperoleh menunjukkan adanya penurunan kejenuhan sebanyak $10 \%$ dari rata-rata pretest sebesar 35\% menjadi $25 \%$ setelah diberi perlakuan pada aspek kelelahan kognitif dengan 11 item pernyataan. Pada tahap ini indikator kesulitan berkonsentrasi dan mudah lupa dalam belajar pada aspek kejenuhan kelelahan kognitif dapat diatasi. Hal ini relevan dengan penelitian Sujatmika et al., (2018) bahwa quantum learning dapat mengoptimalkan otak siswa.

Rayakan. Pada tahap merayakan, guru memutar video dance di mana pada saat itu anggota badan siswa bergerak dengan wajah yang ceria. Pada tahap ini indikator kejenuhan kehilangan semangat belajar pada aspek kehilangan motivasi dan indikator merasa lelah dan letih setiap hari pada aspek kelelahan fisik dapat diatasi. Pada aspek kehilangan motivasi data yang diperoleh menunjukkan adanya penurunan kejenuhan sebanyak $10 \%$ dari rata-rata pretest sebesar $20 \%$ menjadi $10 \%$ setelah diberi perlakuan pada aspek kehilangan motivasi dengan 10 item pernyataan. Berdasarkan data yang diperoleh menunjukkan adanya penurunan kejenuhan sebanyak $9 \%$ dari rata-rata pretest sebesar $28 \%$ menjadi $19 \%$ setelah diberi perlakuan pada aspek kelelahan fisik dengan 5 item pernyataan. Hal ini sesuai yang diungkapkan Syah (2013) tingkat kebugaran organ-organ tubuh dan sendi- sendi dapat dilihat dari kondisi umum jasmani dan tonus (tegangan otot), di mana hal tersebut dapat memengaruhi semangat dan intensitas siswa dalam mengikuti pelajaran. Untuk mempertahan tonus jasmani agar tetap bugar, siswa juga dianjurkan memilih pola istirahat dan olahraga ringan.

Kejenuhan belajar di sekolah harus segera diatasi karna menurut penelitian Boyaci \& Özhan (2018) kejenuhan belajar di sekolah dapat menyebabkan masalah yang serius seperti putus sekolah, kegagalan akademis, dan rendahnya kepercayaan diri. Orang tua, guru dan personil sekolah lain harus berkerjasama dalam proses bimbingan untuk menurunkan kejenuhan belajar siswa. Maka dari itu, berdasarkan hasil penelitian dapat dikatakan bahwa model quantum learning dapat menjadi salah satu upaya untuk menurunkan kejenuhan belajar di sekolah dalam mempelajari kimia.

\section{KESIMPULAN}

Berdasarkan hasil penelitian dapat disimpulkan bahwa model quantum learning berperan sebagai upaya menurunkan kejenuhan belajar siswa dalam mempelajari kimia.

\section{DAFTAR PUSTAKA}

Acat, M. B., \& Yusuf, A.Y. (2014). An Investigation the Effect of Quantum Learning Approach on Primary School 7th Grade Students' Science Achievement, Retention and Attitude. Educational Research Association The International Journal of Research in Teacher Education. 5(2): 11-23.

Aypay, A. (2017). A positive model for reducing and preventing school burnout in high school students. Educational Sciences: Theory \& Practice, 17(4), 1345-1359.

Aro, K.S., \& Upadyaya, K. (2014). School burnout and engagement in the context of demands-resources model. British Journal of Educational Psychology. 84, 137-151.

Boyaci, M., \& Özhan, M. B. (2018). The role of hope and family relations of school burnout among secondary school students: A structural equation modeling. Egitim ve Bilim, 43(195), 137-150.

DePorter, B. \& Mike. (2007). Quantum Learning: membiasakan belajar nyaman dan menyenangkan. Penerjemah, Alwiyah Abdurrahman. Bandung. Penerbit Kaifa.

Hamalik, O. (2010). Psikologi Belajar \& Mengajar. Bandung: Sinar Baru Algensindo.

Güler, M., \& Yazıc1.M. (2018). Kuantum Öğrenme Yaklaşımını Benimseyen Çalışmalara Yönelik Bir Tematik İçerik Analizi. Bayburt Fakultas Pendidikan Journal. 13,93-108.

Iwantara, W., Sadia W., \& Suma K. (2014). Pengaruh Penggunaan Media Video Youtube dalam Pembelajaran IPA Terhadap Motivasi Belajar dan Pemahaman Konsep Siswa. e-Journal Program Pascasarjana Universitas Pendidikan Ganesha Program Studi IPA, 4. 
Martika, W., \& Hermayawati. 2016. Improving Students' Reading Skill by Using Quantum Learning. Journal of English Language and Education, 2, 2.

Maslach, C., \& Leiter M. P. (2007). Burnout. This article is a revision of the previous edition article by C Maslach and MP Leiter, 1, 358-362.

Rahayu, T., Joyoatmojo, S., \& Wahyuni, S. (2016). Penerapan Model Pembelajaran Quantum Learning Dengan Metode Peta Pikiran (Mind Mapping) Sebagai Upaya Meningkatkan Hasil Belajar Siswa Dalam Mempelajari Ekonomi Kelas X 1 SMA N 5 Surakarta Tahun Pelajaran 2015/2016. Jurnal Fakultas Keguruan Dan Ilmu Pendidikan Universitas Sebelas Maret Surakarta.

Ramlan, A.M. (2017). Peningkatan Hasil Belajar Mahasiswa Melalui Metode Quantum Learning Dengan Teknik Mind Mapping. Journal of Educational Science and Technology. 3, 2.

Sardiman. (2014). Interaksi \& Motivasi Belajar Mengajar. Jakarta: Rajawali Pers

Seibert, G. S., May, R. W., Fitzgerald, M.C., \& Fincham, F. D. (2016). Understanding school burnout: Does self-control matter? Learning and Individual Differences, 49, 120-127.

Sujatmika, S., Hasanah, D., \& Hakim, L. L. (2018). Effect of quantum learning model in improving creativity and memory. Journal of Physics: Conference Series, 1006(1).

Sunyono., Wirya, I. W., Suyanto, E., Suyadi, G. (2009). Identifikasi Masalah Kesulitan dalam Pembelajaran Kimia SMA Kelas X di Propinsi Lampung. Jurnal Pendidikan.

Suwidagdho, D. (2016). Efektivitas Terapi Tawa Untuk Menurunkan Tingkat Kejenuhan Belajar PadaSiswa Kelas XI di SMA 11 Yogyakarta. E-Journal Bimbingan dan Konseling Edisi 4 Tahun ke 5

Syah, M. (2013). Psikologi Pendidikan, dengan pendekatan baru. Bandung: PT. Remaja Rosdakarya

Yavuz, G., \& Dogan, N. (2014). Maslach Burnout Inventory-Student Survey (MBI- SS): A Validity Study. Procedia - Social and Behavioral Sciences, 116, 2453-2457.

Zeybek, G. (2017). An Investigation on Quantum Learning Model. International Journal of Modern Education Studies. 1, 1. 